\title{
Management of Infection After Intramedullary Nailing of Long Bone Fractures: Treatment Protocols and Outcomes
}

\author{
Kostas G. Makridis, Theodoros Tosounidis and Peter V. Giannoudis* \\ Academic Department of Trauma and Orthopaedics, Leeds General Infirmary, Clarendon Wing, Level A, Great George \\ Street, LS1 3EX Leeds, UK
}

\begin{abstract}
Implant related sepsis is a relatively unusual complication of intra-medullary nail fixation of long bone fractures. Depending on the extent of infection, timing of diagnosis and progress of fracture union, different treatment strategies have been developed. The aim of this review article is to collect and analyze the existing evidence about the incidence and management of infection following IM nailing of long bone fractures and to recommend treatment algorithms that could be valuable in everyday clinical practice. After searching the $\mathrm{P} \mathrm{u}$ b M e d /Medline databases, 1270 articles were found related to the topic during the last 20 years. The final review included 28 articles that fulfilled the inclusion criteria.

Only a few prospective studies exist to report on the management of infection following IM nailing of long-bone fractures. In general, stage I (early) infections only require antibiotic administration with/without debridement. Stage II (delayed) infections can be successfully treated with debridement, IM reaming, antibiotic nails, and administration of antibiotics. Infected non-unions are best treated with exchange nailing, antibiotic administration and when infection has been eradicated with graft implantation if it is needed. Debridement, exchange nailing and systemic administration of antibiotics is the best indication for stage III (late) infections, while stage III infected non-unions can successfully be treated with nail removal and Ilizarov frame, especially when large bone defects exist.
\end{abstract}

Keywords: Intramedullary nailing, infection, long bone fractures, reaming, review.

\section{INTRODUCTION}

Long bone fractures are severe injuries commonly resulting from high-energy trauma, usually due to roadtraffic collisions. A substantial amount of energy is transferred to the limb leading to damage of both the soft tissue envelope and the bone. Intramedullary (IM) nailing is considered the gold standard of treatment of closed and many open femoral, tibial and humeral shaft fractures due to its biomechanical and biological advantages. The risk of infection following IM nailing of closed long bone fractures is thought to be similar to the general risk of infection after any orthopaedic trauma procedure, but this risk is substantially increased in the setting of open fractures and has been reported to range between $4 \%$ and $7 \%$ [1].

The development of intramedullary sepsis after stabilization of long bone fractures is a dreadful complication and its management has been a topic of vivid discussion [1]. The aim of this review article is to collect and analyze the existing evidence related to the incidence and management of infection following IM nailing of long bone fractures and to recommend treatment algorithms that could be valuable in everyday clinical practice.

\footnotetext{
*Address correspondence to this author at the Academic Department of Trauma and Orthopaedics, School of Medicine, University of Leeds, Leeds General Infirmary, Clarendon wing Level A, Great George Street, LS1 3EX Leeds, UK;

E-mail: pgiannoudi@aol.com
}

\section{MATERIALS AND METHODS}

\section{Literature Search}

We searched the PubMed Medline databases, from January 1992 to December 2012, to retrieve relevant articles reporting on the management of infection following intramedullary nailing of long bone fractures. We manually searched the bibliographies of identified articles and we also used the "related articles" options in PubMed Medline. We restricted our research to studies in English. The keywords used in the subject headings search included: "intramedullary" and "nailing" and "infection".

\section{Criteria for Eligibility}

The studies selected were original articles that fulfilled the following criteria: 1) more than 5 adult patients were included 2) articles were published in English language 3) the full text of the article was available 4) the primary management of long-bone fractures was an intramedullary nail 5) the method of treatment of the infected intra medullary nail was reported; 6) a minimum mean follow-up of 12-months was reported. All articles that did not meet the foregoing criteria including case reports, review articles and editorial comments were excluded.

\section{Extraction of Data}

Relevant information on publication year, type of the study, patient demographics, type of fracture (open or closed), time interval from fracture to intramedullary nailing 
fixation, duration of follow up, type of bacteria isolated, and method of treatment following intramedullary infection were carefully extracted.

Infections were classified into three stages [2]. The first stage (early) was considered as bacterial cellulitis occurring in the immediate postoperative period usually within 2-6 weeks. This situation is usually treatable with high doses of intravenous antibiotics and, as long as stability of the fracture is retained and there is no underlying collection of pus, there is no need for wound exploration or implant removal. If there is an underlying collection then incision and drainage is mandatory. The second stage defined between 2 to 9 months post-operatively, is associated with delayed wound healing, wound necrosis or discharge from the operative site. An impaired fracture healing response might be present. One must assume that there is bone infection present and nail removal, followed by restabilisation of the fracture could be necessary. However, assuming that the implant (nail) still provides a stable mechanical environment, revision of fixation may not be necessary and local soft tissue treatment should be combined with the appropriate administration of antibiotics for suppression of the infection until union is established. The third stage (late) represents established intramedullary osteomyelitis. In this case, principles of management include establishing the extent of non-viable hard and soft tissue (the zone of necrosis) and the extent of infection (the zone of disease). After debridement and irrigation, the most appropriate method of fracture stabilization is carried out if the fracture is still un-united and for any bone loss restoration is performed when an aseptic environment has been achieved with the most appropriate option (ie: bone grafting, bone transport, etc.). If the fracture has united usually implant removal with debridement and irrigation of the IM canal is recommended.

\section{Statistical Analysis}

Comparison of data between the groups was performed on a personal computer using SPSS (17.0.1 for windows, SPSS Inc., Chicago, Illinois). Qualitative data were compared using the chi-squared test. Differences were considered significant at $\mathrm{p}<0.05$.

\section{RESULTS}

\section{Literature Search}

The initial electronic search yielded 1270 articles, 603 of which were potentially eligible based on a scan of the title and the abstract. After obtaining the full text, we found a total of 28 articles meeting the inclusion criteria [3-30]. Study details are illustrated in Table $\mathbf{1 .}$

\section{Demographic Data}

In total, 2128 patients that underwent an intramedullary nailing procedure for the management of a long bone fracture were included. Four studies did not report the sex ratio $[12,14,25,30]$. The remaining studies reported on sex ratio and there were 1020 males and 352 females. The median follow-up was 14.4 months (3-79 months). The median age of patients at the time of the primary intramedullary nailing was 32.5 years (range 15-92). However, the median age of patients was not reported in 3
$[11,19,29]$. Overall, $88.6 \%$ of the fractures were the result of high-energy mechanism. In the majority of the studies the associated injuries, the Injury Severity Score, the time interval from fracture to intramedullary nailing and the duration of the initial intramedullary procedure were poorly documented.

\section{Type of Studies and Fractures}

Only 7 studies were prospective $[6,7,12,13,23,25,26]$, while the rest were of retrospective nature [3-5, 8-11, 14-22, 24, 27-30]. Four studies reported on humeral [3, 5, 13, 20], 6 on femoral $[6,9,14,21,28,29]$ and 18 on tibial fractures [4, $6-8,10-12,14-19,22-27,30]$. In total, there were 2140 diaphyseal fractures in 2128 patients (12 bilateral). There were 981 closed fractures and 1122 open fractures, while 1 study [6] did not report on the type of fractures (37 fractures). There were 141 (109 closed/32 open) humeral, 561 (418 closed/143 open) femoral and 1401 (454 closed/947 open) tibial fractures.

\section{Type of Bacteria Isolated and Time Interval from Injury to Intramedullary Nailing Fixation}

Six studies $[8,11,14,16,29,30]$ reported Staphylococcus Aureus to be the most common causative organism of infection. In one study [14], 11 cultures were negative although clinical manifestation of infection occurred. In ten studies [4, 5, 9, 15, 23, 24, 25, 26, 28, 29] the time interval from injury to the primary intramedullary nailing procedure ranged from 3 hours to 33 days.

\section{Methods of Treatment Following Infection According to Stage of Infection}

Out of 2128 cases, 171 (7.9\%) were reported to develop infection after intramedullary nailing. There were 25 cases of stage I infection $(1.16 \%)$ [3, 4, 5, 9, 11, 12, 19, 26], 120 cases of stage II infection (5.6\%) [7, 9-17, 19, 20, 21, 22, 24-30] and 26 cases of stage III infection (1.2\%) [6, 7, 8, 12, 22, 27, $30]$. All stage I infection cases were successfully treated with nail retaining, incision and drainage where it was felt to be necessary and antibiotic administration. Six methods of treatment were used to treat stage II infections (Table 2). Nail removal followed by placement of an antibiotic nail and nail retainment with extensive soft tissue debridement and administration of antibiotics were used in the majority of cases. No difference in outcomes was noted when comparing these two treatment strategies $(\mathrm{p}<0.417)$. Other treatment options included nail retainment with antibiotic administration and following fracture union, removal of nail and reaming and irrigation of the IM canal; exchange nailing complimented with appropriate antibiotic administration; and nail removal, reaming and application of Ilizarov frame. No difference in outcomes was noted comparing the different methods of treatment $(\mathrm{p}<0.353$ and $\mathrm{p}<0.189$ respectively). Stage II infected non-unions were treated using 3 strategies (Table 2). There were statistically significant differences in favor of nail retainment/debridement/antibiotic administration and exchange nail/antibiotics/ \pm bone graft compared to nail removal/external fixation $(\mathrm{p}<0.015$ and $\mathrm{p}<0.028$ respectively). Stage III infections were managed with 3 methods, but samples were not sufficient to safely compare their effectiveness (Table 2). 
Table 1. Studies Analysed Reporting on Type of Fracture and Type of Nail Used

\begin{tabular}{|c|c|c|c|c|c|c|}
\hline & Type of Study & $\begin{array}{c}\text { Number } \\
\text { of } \\
\text { Patients }\end{array}$ & $\begin{array}{c}\text { Mean Age } \\
\text { Years (Range) }\end{array}$ & $\begin{array}{c}\text { Mean Follow- } \\
\text { Up } \\
\text { Months }\end{array}$ & $\begin{array}{l}\text { Type of } \\
\text { Fracture }\end{array}$ & $\begin{array}{l}\text { Type of } \\
\text { Nail }\end{array}$ \\
\hline Giannoudis, 2012 & Retrospective case series & 25 & $61(18-92)$ & $36(27-43)$ & Humerus & Antegrade \\
\hline Sekimpi , 2011 & Retrospective case series & 50 & $31(15-71)$ & 12 & Femur & $\begin{array}{l}\text { Antegrade } \\
\text { Retrograde }\end{array}$ \\
\hline Tsourvakas, 2011 & Retrospective case series & 52 & $51.7(18-72)$ & 18 & Humerus & Antegrade \\
\hline Ikpeme, 2011 & Prospective & 35 & $35 \pm 11.9(15-61)$ & $22 \pm 5.32$ & Tibia & $\begin{array}{l}\text { Not clear } \\
\text { reported }\end{array}$ \\
\hline Vallier, 2011 & Prospective & 56 & 38.1 (not reported) & 19.9 & $\begin{array}{l}\text { Femur - } \\
\text { Tibia }\end{array}$ & Antegrade \\
\hline Megas, 2010 & Retrospective case series & 9 & $39.7(21-75)$ & $26.6(13-42)$ & Tibia & Antegrade \\
\hline Karadimas, 2009 & Retrospective case series & 415 & $27.8(17-84)$ & $18(12-36)$ & Femur & Antegrade \\
\hline Lindvall, 2009 & Retrospective cohort & 22 & Not reported & $40.8(15-67)$ & Tibia & Antegrade \\
\hline Aderinto, 2008 & $\begin{array}{l}\text { Retrospective with control } \\
\text { group }\end{array}$ & 54 & Not reported & $13(3-40)$ & Tibia & Antegrade \\
\hline Kakar, 2007 & Prospective & 143 & Not reported(16-83) & $26.4(7.2-66)$ & Tibia & Antegrade \\
\hline Changulani, 2007 & Prospective & 23 & $39 \pm 12$ (not reported) & $14.3(6-33)$ & Humerus & Antegrade \\
\hline Qiang, 2007 & Retrospective case series & 19 & Not reported & Not reported & Femur-Tibia & Antegrade \\
\hline Oh, 2006 & Retrospective case series & 23 & $38.6(17-70)$ & Not reported & Tibia & Antegrade \\
\hline Tang, 2006 & $\begin{array}{c}\text { Retrospective database } \\
\text { analysis }\end{array}$ & 117 & $35.7(15-83)$ & $14.3(3.1-70.5)$ & Tibia & Antegrade \\
\hline Petrisor, 2005 & $\begin{array}{c}\text { Retrospective case series } \\
\text { review }\end{array}$ & 35 & $\begin{array}{l}\text { Not reported exactly (14- } \\
77)\end{array}$ & Not reported & Tibia & Antegrade \\
\hline Nork, 2005 & Retrospective case series & 36 & $30(18-80)$ & $10.8-72$ & Tibia & Antegrade \\
\hline Shah, 2004 & Retrospective case series & 32 & $26(15-54)$ & 14 & Tibia & Antegrade \\
\hline Stannard, 2003 & Retrospective case series & 41 & $>17($ not reported) & $22(7-42)$ & Humerus & Not reported \\
\hline Chen, 2003 & Retrospective case series & 23 & Not reported(15-69) & $12-79$ & Femur & Not reported \\
\hline Keating, 2000 & Retrospective case series & 57 & $36(15-78)$ & $41(12-79)$ & Tibia & Antegrade \\
\hline Uhlih, 1998 & Prospective & 55 & $40(13-77)$ & Not reported & Tibia & Antegrade \\
\hline Huang, 1997 & Retrospective case series & 33 & $56(18-79)$ & $48(12-84)$ & Tibia & Antegrade \\
\hline Blachut, 1997 & Prospective & 135 & 35 (not reported) & $12(3-33)$ & Tibia & Antegrade \\
\hline Keating, 1997 & Prospective & 86 & $37(16-88)$ & $22(14-44)$ & Tibia & Antegrade \\
\hline Robinson, 1995 & Retrospective case series & 29 & $40.8(18-78)$ & $38(6-78)$ & Tibia & Antegrade \\
\hline Rutter, 1994 & Retrospective case series & 27 & $28(16-46)$ & Not reported & Femur & Antegrade \\
\hline Nowotarski, 1994 & Retrospective case series & 37 & $26(15-50)$ & $12.5(6-40)$ & Femur & Antegrade \\
\hline $\begin{array}{c}\text { Court-Brown, } \\
1992\end{array}$ & Retrospective case series & 459 & Not reported & Not reported & Tibia & Antegrade \\
\hline
\end{tabular}

Stage III infected non-unions were successfully treated using 2 procedures (Table $\mathbf{2}$ ).

\section{DISCUSSION}

Long-bone fractures are common orthopaedic injuries and usually occur in the setting of severe trauma. Since its introduction by Kuntscher, intramedullary nailing has become the choice of treatment of stabilisation of diaphyseal long bone fractures [31, 32]. Intramedullary nailing is a technically demanding procedure that requires vigilance and careful planning in order to achieve an optimal outcome. Major complications following this procedure include infection, compartment syndrome, venous thrombo-embolic events, fat embolism syndrome, neurovascular damage and non-union. All these complication could have a significant impact on the functional outcome of patients [33].

The incidence of infection following closed long-bone fractures is approximately $1-2 \%$ [34]. This incidence is 
Table 2. Treatment Methods According to the Stage of Infection

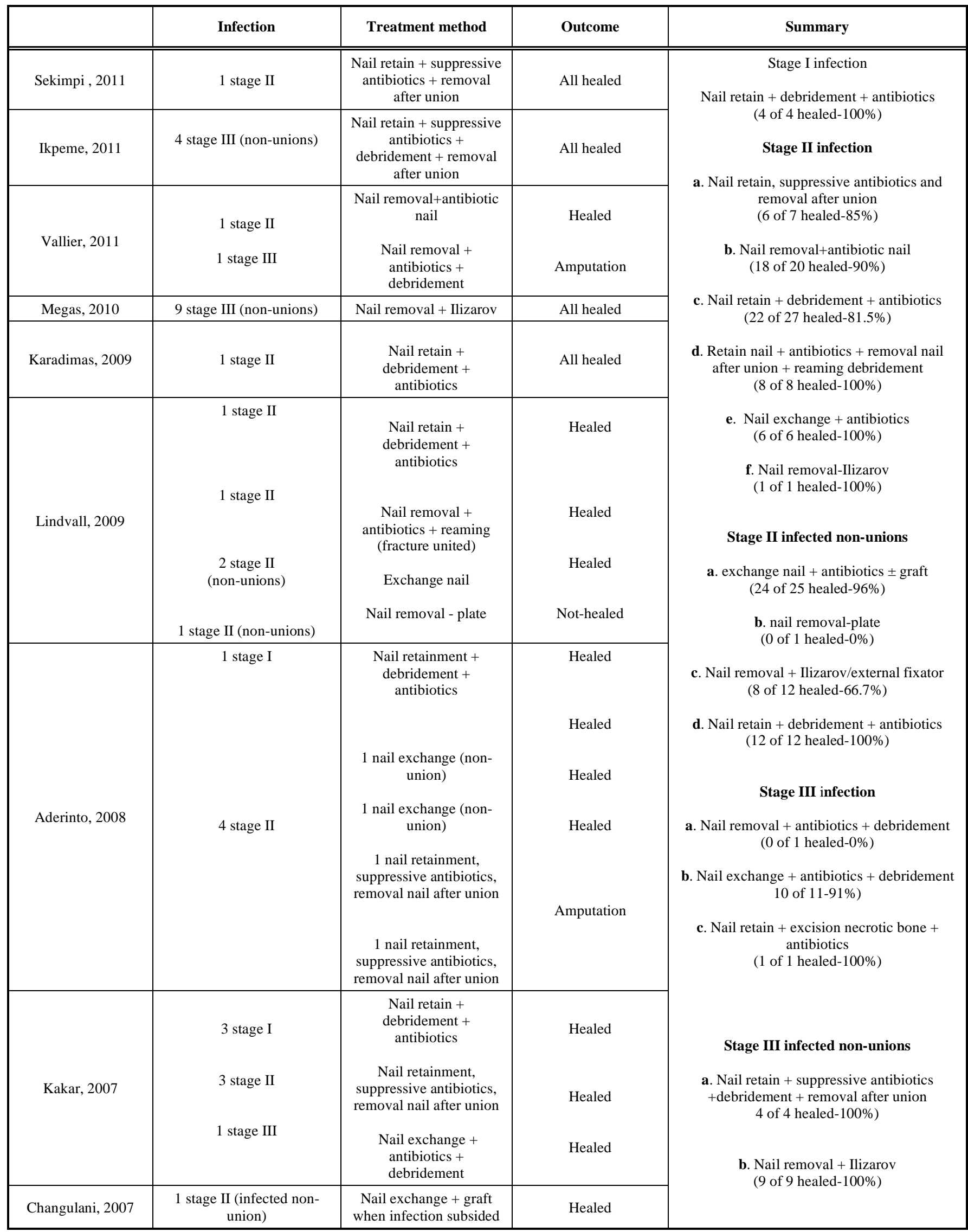


(Table 2) contd.....

\begin{tabular}{|c|c|c|c|c|}
\hline & Infection & Treatment method & Outcome & Summary \\
\hline Qiang, 2007 & 19 stage II & $\begin{array}{c}\text { Nail removal + } \\
\text { antibiotic nail }\end{array}$ & $\begin{array}{c}17 \text { healed } \\
1 \text { amputation } \\
1 \text { infected non-union }\end{array}$ & \\
\hline Oh, 2006 & 2 stage II & $\begin{array}{l}1 \text { Nail removal-Ilizarov } \\
1 \text { Nail retain }+ \\
\text { debridement }+ \\
\text { antibiotics }\end{array}$ & $\begin{array}{l}\text { Healed } \\
\text { Healed }\end{array}$ & \\
\hline Tang, 2006 & 2 stage II (1 non-union) & $\begin{array}{c}1 \text { Nail retainment }+ \\
\text { debridement }+ \\
\text { antibiotics } \\
1 \text { Nail exchange (non- } \\
\text { union) }\end{array}$ & $\begin{array}{l}\text { Healed } \\
\text { Healed }\end{array}$ & \\
\hline Petrisor, 2005 & 35 stage II (19 non-unions) & $\begin{array}{c}10 \text { Nail retainment }+ \\
\text { antibiotics }+ \\
\text { debridement } \\
7 \text { Nail exchange (non- } \\
\text { unions) } \\
11 \text { Nail exchange + graft } \\
\text { (non-unions) } \\
1 \text { nail removal + Ilizarov } \\
\text { (non-union) } \\
\\
4 \text { retainment }+ \\
\text { antibiotics } \\
2 \text { attempts for } \\
\text { reconstruction }\end{array}$ & $\begin{array}{c}\text { Healed } \\
\text { Healed } \\
\text { Healed (1 finally } \\
\text { amputation) } \\
\text { Healed } \\
\text { Amputation }\end{array}$ & \\
\hline Shah, 2004 & 1 stage II & $\begin{array}{l}\text { Nail retainment }+ \\
\text { debridement }+ \\
\text { antibiotics }\end{array}$ & Healed & \\
\hline Stannard, 2003 & 1 stage II & $\begin{array}{l}\text { Nail retainment }+ \\
\text { debridement }+ \\
\text { antibiotics }\end{array}$ & Healed & \\
\hline Chen, 2003 & 23 stage II (all non-unions) & 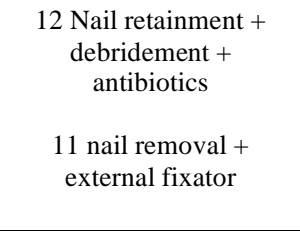 & $\begin{array}{c}\text { Healed } \\
7 \text { healed } \\
2 \text { amputations } \\
2 \text { still non-union }\end{array}$ & \\
\hline Keating, 2000 & $\begin{array}{l}5 \text { stage II } \\
3 \text { stage III }\end{array}$ & $\begin{array}{c}\text { Nail retainment + } \\
\text { debridement + } \\
\text { antibiotics } \\
\text { Nail exchange + } \\
\text { antibiotics + } \\
\text { debridement }\end{array}$ & $\begin{array}{c}4 \text { healed }-1 \\
\text { amputation } \\
\text { Healed }\end{array}$ & \\
\hline Huang, 1997 & 2 stage II & $\begin{array}{c}\text { Nail removal + reaming } \\
\text { + antibiotics (fractures } \\
\text { had united) }\end{array}$ & Healed & \\
\hline Blachut, 1997 & 1 stage II & $\begin{array}{l}\text { Nail retainment + } \\
\text { debridement + } \\
\text { antibiotics }\end{array}$ & Healed & \\
\hline Keating, 1997 & 1 stage II (non-union) & $\begin{array}{c}\text { Nail exchange }+ \\
\text { antibiotics }\end{array}$ & Healed & \\
\hline Robinson, 1995 & $\begin{array}{l}4 \text { stage II } \\
2 \text { stage III }\end{array}$ & $\begin{array}{c}\text { Nail exchange }+ \\
\text { antibiotics }+ \\
\text { debridement }\end{array}$ & Healed & \\
\hline
\end{tabular}


(Table 2) contd.....

\begin{tabular}{|c|c|c|c|c|}
\hline & Infection & Treatment method & Outcome & Summary \\
\hline Rutter, 1994 & 1 stage II & $\begin{array}{c}\text { Nail exchange }+ \\
\text { antibiotics }+ \\
\text { debridement }\end{array}$ & Healed & \\
\hline Nowotarski, 1994 & 1 stage II & $\begin{array}{l}\text { Keep nail initially }+ \\
\text { suppressive antibiotics + } \\
\text { after nail removal + } \\
\text { reaming + reinsertion } \\
\text { larger diameter nail }\end{array}$ & Healed & \\
\hline Court-Brown, 1992 & $\begin{array}{l}6 \text { stage II } \\
6 \text { stage III }\end{array}$ & 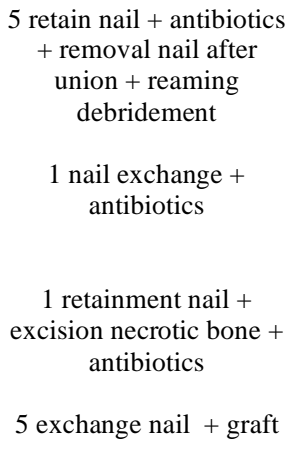 & $\begin{array}{l}\text { Healed } \\
\text { Healed } \\
\text { Healed } \\
4 \text { healed (1 } \\
\text { amputation) }\end{array}$ & \\
\hline
\end{tabular}

considerably higher in open fractures (for Gustilo-Anderson Type I fractures 5\%, for Type II 10\% and for Type III over $15 \%$, respectively) [35-37]. Previous studies have shown that intramedullary nail fixation provides a stable construct which allows a fracture to heal even in the presence of sepsis [37]. Changulani et al. prospectively compared IM nailing with compression plating in humeral fractures and found lower infection rates using the former, emphasizing the importance of surgical technique in terms of union time and major complications [13]. On the other hand, Vallier et al. compared plate versus IM nail fixation for distal tibial shaft fractures and they found equal incidence of infection in the two groups. The critical factor influencing the risk of developing infection was the complexity of the fracture and not the technique used [7]. Blachut et al. concluded that there is no major advantage to nailing without reaming compared to nailing with reaming for the treatment of closed fractures of the shaft of the tibia. In their prospective randomized study there was only one deep infection in 135 patients that occurred after unreamed nailing. There was no significant difference compared to reamed nailing [25].

A meticulous clinical evaluation, a detailed diagnostic workup, and a specific treatment strategy are critical factors in diagnosing the presence of infection after surgical fixation of long-bone fractures [38]. Criteria for clinical infection include an open wound with a draining sinus, fever, persistent pain and local signs of inflammation. The laboratory workup includes a full blood cell count, Creactive protein and erythrocyte sedimentation rate which along imaging studies can lead to an accurate diagnosis of an underlying infection [39]. The culture of the infected tissue provides the final diagnosis [39]. Forsberg et al. [40], have reported on their review that cross-sectional imaging is critical to delineate the extent of bony involvement, and scintigraphy can be used as a diagnostic tool and to gauge response to treatment. The authors proposed an oncologic approach in order to diagnose and manage an infection beginning from clinical staging and ending to a complete debridement of the affected tissue.

The management of complications after long bone intramedullary nailing may be complex and should be ideally delegated to specialized orthopaedic traumatologists. Different strategies for treatment of infection after IM nailing have been reported by several authors. Some of them involve retainment of the nail, thorough irrigation and softtissue debridement followed by intravenous administration of antibiotics [41]. This method considers union of the fracture as the most important factor and secondarily deals with the infection. The second strategy aims to the eradication of the infection as the main objective and involves removal of the infected nail, debridement, antibiotics and the insertion of a new nail in order to achieve fracture union. The main drawback of this method is that soft-tissue and bone debridement can lead to sizeable defects $\mathrm{t} h$ e reconstruction of which requires additional skills and expertise [42].

In this study, we tried to identify the contemporary used methods for the management of infection following intramedullary nailing of long-bone fractures. We have classified infection in 3 distinct clinical stages attempting to analyze the effectiveness of treatment strategies used in the relevant publications. Thus, the methods of treatment depending on the stage of infection and the progress of fracture union were analyzed.

In 28 studies reviewed, only few reported on a specific treatment protocol used for the diagnosis of infections $[6,16$, $27,30]$, although most of the papers seemed to follow the general diagnostic guidelines. Considering treatment strategies, stage I infection was successfully treated with nail retainment, debridement when necessary and pathogen specific antibiotic administration $[11,12]$. Stage II infections were reported to heal successfully either with nail retainment, antibiotics and removal of nail with reaming of the IM canal after fracture union [24, 29, 30] or with nail 


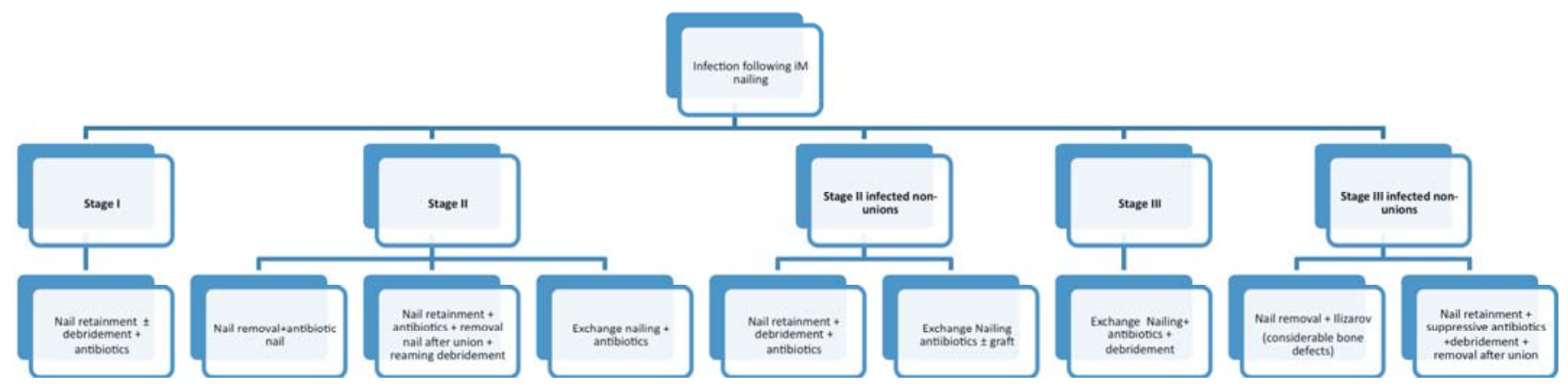

Fig. (1). Proposed algorithm for the treatment of infection following IM nailing of long-bone fractures.

removal and new antibiotic nail placement [7, 14]. An alternative option could be an exchange nailing procedure with antibiotic administration, although the burden of surgery is greater $[27,28,30]$. However, based on the data analyzed, no significant differences were noted comparing all 6 suggested treatment strategies. With regard to the management of infected non-unions, exchange nailing in combination with antibiotics and with/without bone grafting can lead to successful eradication of the infection and fracture union $[10,11,13,16,17,22]$.

According to the data analyzed, it was noted that stage III infections are better managed with debridement, exchange nailing and antibiotic administration [12, 22, 27, 30]. Finally, for stage III infected non-unions it appears that the Ilizarov method is most commonly used with good results especially when significant bone defects exist [8].

Despite the promising results and satisfactory functional and radiological outcomes that have been reported, our study has a number of limitations. Firstly, we noted a great heterogeneity amongst the studies analyzed. Secondly, the vast majority of the studies were retrospective case series. Thirdly, a lot of studies failed to provide the same information required to be able to do a direct comparison of the treatment strategies used and outcomes. Despite the above limitations and based on the available evidence an algorithm was developed which could be useful to clinicians managing these complex cases (Fig. 1).

\section{CONCLUSION}

The treatment of infection following IM nailing of longbone fractures remains challenging and the surgeon has to consider the most appropriate treatment option in order to achieve the best clinical results and minimize the risk of revision surgery. Prompt clinical examination and laboratory screening is mandatory for early diagnosis. The results available in literature are variable and only few prospective studies exist to report on the management of infection following IM nailing of long-bone fractures.

A useful tool is to classify infection according to location and timing of presentation. In general, stage I infections only require antibiotic administration with/without debridement. Stage II infections can be successfully treated with antibiotic nails, exchange nailing or removal of the nail after fracture union and intramedullary reaming. Infected non-unions are best treated with exchange nailing, antibiotic administration with/without grafting at a later stage. Stage III infected nonunions can successfully be treated with nail removal and
Ilizarov frame application, especially when large bone defects exist.

\section{CONFLICT OF INTEREST}

The authors confirm that this article content has no conflict of interest.

\section{ACKNOWLEDGEMENTS}

Declared none.

\section{REFERENCES}

[1] Young S, Lie SA, Hallan G, Zirkle LG, Engesæter LB, Havelin LI. Risk Factors for Infection after 46,113 Intramedullary Nail Operations in Low- and Middle-income Countries. World J Surg 2013; 37(2): 349-55.

[2] Romano CL, Romano D, Logoluso N, Drago L. Bone and joint infections in adults: a comprehensive classification proposal. Eur Orthop Traumatol 2011; 1(6): 207-17.

[3] Giannoudis PV, Xypnitos FN, Dimitriou R, Manidakis N, Hackney R. Internal fixation of proximal humeral fractures using the Polarus intramedullary nail: our institutional experience and review of the literature. J Orthop Surg Res 2012; 7(1): 39.

[4] Sekimpi P, Okike K, Zirkle L, Jawa A. Femoral fracture fixation in developing countries: an evaluation of the Surgical Implant Generation Network (SIGN) intramedullary nail. J Bone Joint Surg Am 2011; 93(19): 1811-8.

[5] Tsourvakas S, Alexandropoulos C, Papachristos I, Tsakoumis G, Ameridis N. Treatment of humeral shaft fractures with antegrade intramedullary locking nail. Musculoskelet Surg 2011; 95(3): 1938.

[6] Ikpeme I, Ngim N, Udosen A, Onuba O, Enembe O, Bello S. External jig-aided intramedullary interlocking nailing of diaphyseal fractures: experience from a tropical developing centre. Int Orthop 2011; 35(1): 107-11.

[7] Vallier HA, Cureton BA, Patterson BM. Randomized, prospective comparison of plate versus intramedullary nail fixation for distal tibia shaft fractures. J Orthop Trauma 2011; 25(12): 736-41.

[8] Megas P, Saridis A, Kouzelis A, Kallivokas A, Mylonas S, Tyllianakis $M$. The treatment of infected nonunion of the tibia following intramedullary nailing by the Ilizarov method. Injury 2010; 41(3): 294-9.

[9] Karadimas EJ, Papadimitriou G, Theodoratos G, Papanikolaou A, Maris J. The effectiveness of the antegrade reamed technique: the experience and complications from 415 traumatic femoral shaft fractures. Strategies Trauma Limb Reconstr 2009; 4(3): 113-21.

[10] Lindvall E, Sanders R, Dipasquale T, Herscovici D, Haidukewych G, Sagi C. Intramedullary nailing versus percutaneous locked plating of extra-articular proximal tibial fractures: comparison of 56 cases. J Orthop Trauma 2009; 23(7): 485-92.

[11] Aderinto J, Keating JF. Intramedullary nailing of fractures of the tibia in diabetics. J Bone Joint Surg Br 2008; 90(5): 638-42.

[12] Kakar S, Tornetta P 3rd. Open fractures of the tibia treated by immediate intramedullary tibial nail insertion without reaming: a prospective study. J Orthop Trauma 2007; 21(3): 153-7.

[13] Changulani M, Jain UK, Keswani T. Comparison of the use of the humerus intramedullary nail and dynamic compression plate for the 
management of diaphyseal fractures of the humerus. A randomised controlled study. Int Orthop 2007; 31(3): 391-5.

[14] Qiang Z, Jun PZ, Jie XJ, Hang L, Bing LJ, Cai LF. Use of antibiotic cement rod to treat intramedullary infection after nailing: preliminary study in 19 patients. Arch Orthop Trauma Surg 2007; 127(10): 945-51.

[15] Oh CW, Bae SY, Jung DY, Oh JK. Treatment of open tibial shaft fractures using tightly fitted interlocking nailing. Int Orthop 2006; 30(5): 333-7.

[16] Tang P, Gates C, Hawes J, Vogt M, Prayson MJ. Does open reduction increase the chance of infection during intramedullary nailing of closed tibial shaft fractures? J Orthop Trauma 2006; 20(5): 317-22.

[17] Petrisor B, Anderson S, Court-Brown CM. Infection after reamed intramedullary nailing of the tibia: a case series review. J Orthop Trauma 2005; 19(7): 437-41.

[18] Nork SE, Schwartz AK, Agel J, Holt SK, Schrick JL, Winquist RA. Intramedullary nailing of distal metaphyseal tibial fractures. J Bone Joint Surg Am 2005; 87(6): 1213-21.

[19] Shah RK, Moehring HD, Singh RP, Dhakal A. Surgical Implant Generation Network (SIGN) intramedullary nailing of open fractures of the tibia. Int Orthop 2004; 28(3): 163-6.

[20] Stannard JP, Harris HW, McGwin G Jr, Volgas DA, Alonso JE, Intramedullary nailing of humeral shaft fractures with a locking flexible nail. J Bone Joint Surg Am 2003; 85-A(11): 2103-10.

[21] Chen CE, Ko JY, Wang JW, Wang CJ. Infection after intramedullary nailing of the femur. J Trauma 2003; 55(2): 338-44.

[22] Keating JF, Blachut PA, O'Brien PJ, Court-Brown CM. Reamed nailing of Gustilo grade-IIIB tibial fractures. J Bone Joint Surg Br 2000; 82(8): 1113-6.

[23] Uhlin B, Hammer R. Attempted unreamed nailing in tibial fractures: a prospective consecutive series of 55 patients. Acta Orthop Scand 1998; 69(3): 301-5.

[24] Huang CK, Chen WM, Chen TH, Lo WH. Segmental tibial fractures treated with interlocking nails. A retrospective study of 33 cases. Acta Orthop Scand 1997; 68(6): 563-6.

[25] Blachut PA, O'Brien PJ, Meek RN, Broekhuyse HM. Interlocking intramedullary nailing with and without reaming for the treatment of closed fractures of the tibial shaft. A prospective, randomized study. J Bone Joint Surg Am 1997; 79(5): 640-6.

[26] Keating JF, O'Brien PJ, Blachut PA, Meek RN, Broekhuyse HM. Locking intramedullary nailing with and without reaming for open fractures of the tibial shaft. A prospective, randomized study. J Bone Joint Surg Am 1997; 79(3): 334-41.

[27] Robinson CM, McLauchlan G, Christie J, McQueen MM, CourtBrown CM. Tibial fractures with bone loss treated by primary reamed intramedullary nailing. J Bone Joint Surg Br 1995; 77(6): 906-13.

[28] Rütter JE, de Vries LS, van der Werken C. Intramedullary nailing of open femoral shaft fractures. Injury 1994; 25(7): 419-22.

[29] Nowotarski P, Brumback RJ. Immediate interlocking nailing of fractures of the femur caused by low- to mid-velocity gunshots. J Orthop Trauma 1994; 8(2): 134-41.

[30] Court-Brown CM, Keating JF, McQueen MM. Infection after intramedullary nailing of the tibia. Incidence and protocol for management. J Bone Joint Surg Br 1992; 74(5): 770-4.

[31] Bong MR, Kummer FJ, Koval KJ, Egol KA. Intramedullary nailing of the lower extremity: biomechanics and biology. J Am Acad Orthop Surg 2007; 15(2): 97-106.

[32] Hiesterman TG, Shafiq BX, Cole PA. Intramedullary nailing of extra-articular proximal tibia fractures. J Am Acad Orthop Surg 2011; 19(11): 690-700.

[33] Ricci WM, Gallagher B, Haidukewych GJ. Intramedullary nailing of femoral shaft fractures: current concepts. J Am Acad Orthop Surg 2009; 17(5): 296-305.

[34] Duan X, Al-Qwbani M, Zeng Y, Zhang W, Xiang Z. Intramedullary nailing for tibial shaft fractures in adults. Cochrane Database Syst Rev 2012; 1: CD008241.

[35] Henley MB, Chapman JR, Agel J, Harvey EJ, Whorton AM, Swiontkowski MF. Treatment of type II, IIIA, and IIIB open fractures of the tibial shaft: a prospective comparison of unreamed interlocking intramedullary nails and half-pin external fixators. $\mathbf{J}$ Orthop Trauma 1998; 12: 1-7.

[36] Guo JJ, Tang N, Yang HL, Tang TS. A prospective, randomised trial comparing closed intramedullary nailing with percutaneous plating in the treatment of distal metaphyseal fractures of the tibia. J Bone Joint Surg Br 2010; 92(7): 984-8.

[37] Littenberg B, Weinstein LP, McCarren M, et al. Closed fractures of the tibial shaft. A meta-analysis of three methods of treatment. J Bone Joint Surg Am 1998; 80(2): 174-83.

[38] Athanasou NA, Simpson AHR, Wood MK. Histological assessment of the presence or absence of infection in fracture nonunion. Injury 2002; 33: 151-5.

[39] Matthews PC, Berendt AR, McNally MA, Byren I. Diagnosis and management of prosthetic joint infection. BMJ 2009; 338: b1773.

[40] Forsberg JA, Potter BK, Cierny G 3rd, Webb L. Diagnosis and management of chronic infection. J Am Acad Orthop Surg. 2011; 19 Suppl 1: S8-S19.

[41] Motsitsi NS. Management of infected nonunion of long bones: the last decade (1996-2006). Injury 2008; 39(2): 155-60.

[42] Eshima I, Feibel RJ, Louie KW, Lowenberg DW. Combined muscle flap and Ilizarov reconstruction for bone and soft tissue defects. Clin Orthop Relat Res 1996; (332): 37-51.

(C) Makridis et al.; Licensee Bentham Open.

This is an open access article licensed under the terms of the Creative Commons Attribution Non-Commercial License (http://creativecommons.org/licenses/by-nc/3.0/) which permits unrestricted, non-commercial use, distribution and reproduction in any medium, provided the work is properly cited. 